\title{
The University of Jordan E-Learning Platform: State, Students' Acceptance and Challenges
}

\author{
Tamara Almarabeh, Hiba Mohammad, Rana Yousef, Yousef Kh. Majdalawi \\ Department of Computer Information Systems, King Abdullah II School for Information Technology, \\ The University of Jordan, Amman, Jordan \\ Email: t.almaraabeh@ju.edu.jo, h.khadrawi@ju.edu.jo, rana.yousef@ju.edu.jo, ymajdal@ju.edu.jo
}

Received 27 September 2014; revised 19 October 2014; accepted 12 November 2014

Copyright (C) 2014 by authors and Scientific Research Publishing Inc.

This work is licensed under the Creative Commons Attribution International License (CC BY). http://creativecommons.org/licenses/by/4.0/

c) (7) Open Access

\section{Abstract}

The rapid changes and increased complexity in today's world present new challenges and put new demands on the education system. There has been generally a growing awareness of the necessity to change and improve the existing system towards online learning. Jordan is one of the distinguished countries in the Middle East with rapid progress in education and with advanced teaching and learning technologies. The University of Jordan is trying to exploit Information and Communication Technology (ICT) in education and moving forward by introducing the latest E-learning management systems (LMSs) to keep pace of technological revolution in the higher education. It is important to find out the impact of E-learning management system in the University of Jordan, examine the students' acceptance for this new system and address the challenges facing the students while using the E-learning management system and these are what this paper is trying to do.

\section{Keywords}

Moodle, E-Learning, Blackboard, Technology Acceptance Model, Jordan

\section{Introduction}

Learning is a complex process that can be formed and enhanced by personalized learning (for instance, online and blended learning). The Information and Communication Technology (ICT) has created new spaces in the construction of knowledge and has made contribution to the traditional education by developing new technologies and creating methods and tools to support the learning process and activities [1] [2].

As information technology (IT) becomes more robust and much easier to use, it increasingly deploys the 
technology to many academic activities in higher education [3]. The time for learning is no longer limited to a certain place and period of time (anytime, anyplace and anywhere learning). The concepts, E-learning, distance education, collaborative work, Mobile Learning (M-Learning) and Web-Based Learning (WBL), etc., have all become increasingly important in higher education and educational communities as standard components in many courses.

The term E-learning assigned to Electronic learning was defined by many researchers. For example, [4] defined E-learning as "The delivery of education (all activities relevant to instructing, teaching and learning) through various electronic media. The electronic medium could be the Internet, intranets, extranets, satellite TV, video/audio tape and/or CD ROM".

Other researchers gave a very simple definition. They defined E-learning as a learning which was supported and/or made possible by the use of modern ICT and computers [5]-[7]. In this paper the term E-learning is used to represent open and flexible learning.

In Jordan, numerous universities are offering E-learning tools that can offer simple and safe sites (portal), such as Moodle and Blackboard, to help students and teachers to introduce the contents of courses in simple and effective way and to facilitate the online collaborations: teacher to teacher, teacher to student or student to student.

The structure of this paper is organized as follows. Section 2 provides a literature review of E-learning. Then the E-learning framework which is adopted from Khan's framework is presented after deploying it on the University of Jordan. The factors that affect the students' usage of LMS and the Challenges that face the students during using Moodle as the University of Jordan new E-learning platform are discussed in Section 3. Finally, Section 4 presents the conclusion.

\section{Literature Review}

E-learning is an ICT enhanced learning process, where ICT tools are used to improve the online learning process and activities.

There are basically four types of E-learning systems: the Learning Management System (LMS), Learning Content Management System (LCMS), Learning Design System (LDS) and Learning Support System (LSS) [8]. For the purpose of this paper, the researchers will focus on LMS, which is an E-learning system used by various universities all over the globe. Meanwhile, the LMS is also known in various universities as Virtual Learning Environment or Course Management System [9].

Research on the teaching and learner usability for LMSs has been growing steadily for a number of years [10]-[12]. It provides an environment for learning and teaching without the restrictions of time or distance.

The authors in [13] defined LMS as a web based technology which assists in the planning, distribution and evaluation of a specific learning process. It is a software environment designed to manage user learning interventions as well as deliver learning content and resources to students.

Simonson [14] provided a practical definition of LMSs: software systems designed to assist in the management and administration of educational courses for students and teachers. The systems can often track the learners' progress; they are also used to support the face-to-face classroom.

Based on the literature review, some of the benefits of E-learning are listed below:

- Saving money: The traditional learning incurs substantial delivery costs, production costs, travelling cost, set up and material cost. Using E-learning, on the other hand, incurs only production and small implementation costs. When the material is uploaded online, no expire dare and could be utilized anywhere [15].

- Affectivity: E-learning combines a variety of rich media i.e. audio, video, presentations, etc. Each learner can choose his/her learning style. Also the E-learning gives more control to the learner by starting over, revisiting or replay segments which is impossible to do in the traditional classroom.

- Accessibility: E-learning allows learners to access the material anytime and anywhere at their preferred pace without stress of missing important information [16].

\section{The University of Jordan E-Learning}

The E-learning initiative in Jordan is a national initiative of his Majesty King Abdullah II which is part of a larger national IT strategy to grow internet use, where his Majesty King Abdullah II strongly believes that the Information and Communication Technology (ICT) sector offers great potential to positively shape the future of 
education systems in the kingdom [17].

The vision of E-learning in Jordan is "Enhancing the quality of education and inspiring lifelong learning through E-learning". The University of Jordan translated this vision by introducing an environment where the use of ICT becomes an integral part of the university daily management and practices [18] [19].

A study [20] reviewed the status of E-learning in Jordan in SWOT model showed that Jordanian learners have sufficient awareness of the importance of E-learning, the factors that help in the success and the challenges of such project and explained that the implementation process is gradual and needs patience, encouragement, and continuous technical support.

The University of Jordan was established in 1962. It has 19 faculties, 2 deanships and 15 centers in the main campus in Amman in addition to 5 faculties in Aqaba branch. The University of Jordan (http://www.ju.edu.jo) was using Blackboard in 2005 as E-learning platform. Because of the increase in the annual licensing costs for the proprietary system, the Blackboard system was replaced by the Open Source Moodle system. The University of Jordan started to use Moodle in 2012 instead of Blackboard as its main LMS, but the usage is still in the infancy stage, i.e. the teacher can upload the course description, assignments, news about the courses. The students can check these announcements, download the assignments, solve them and upload them again on LMS. The web-based communication tools have given the online education a new edge [9].

The University of Jordan E-learning initiative has four plans of action [18] [19]:

- The deployment of the necessary infrastructure and equipment for sparking the growth of E-learning;

- Specific training at all levels and particularly for teachers, students and administrative staff;

- The creation of the necessary conditions for the development of quality educational contents and services;

- Hastening the networking and cooperation at the national level.

\subsection{E-Learning Platform at the University of Jordan}

Different universities in different countries have responded to E-learning differently according to the regulations. Regarding the University of Jordan, it adopted the blended learning approach, which is a hybrid of face to face learning and online learning. Which means the students attend face to face lectures; at the same time all learning materials are provided online for students.

Moodle is used in the University of Jordan to design a well formed E-learning platform and learning management system (LMS). After launching the LMS site a webpage will be shown as you see in Figure 1 asking the users for their authentication. LMS users at the University of Jordan are classified into five categories according to their authorities: administrator, creator, an editing-teacher, non-editing teacher, student and guest where each one has different roles.

The University of Jordan E-learning platform is adopted from Khan's framework which can be seen in Figure 2 [21].

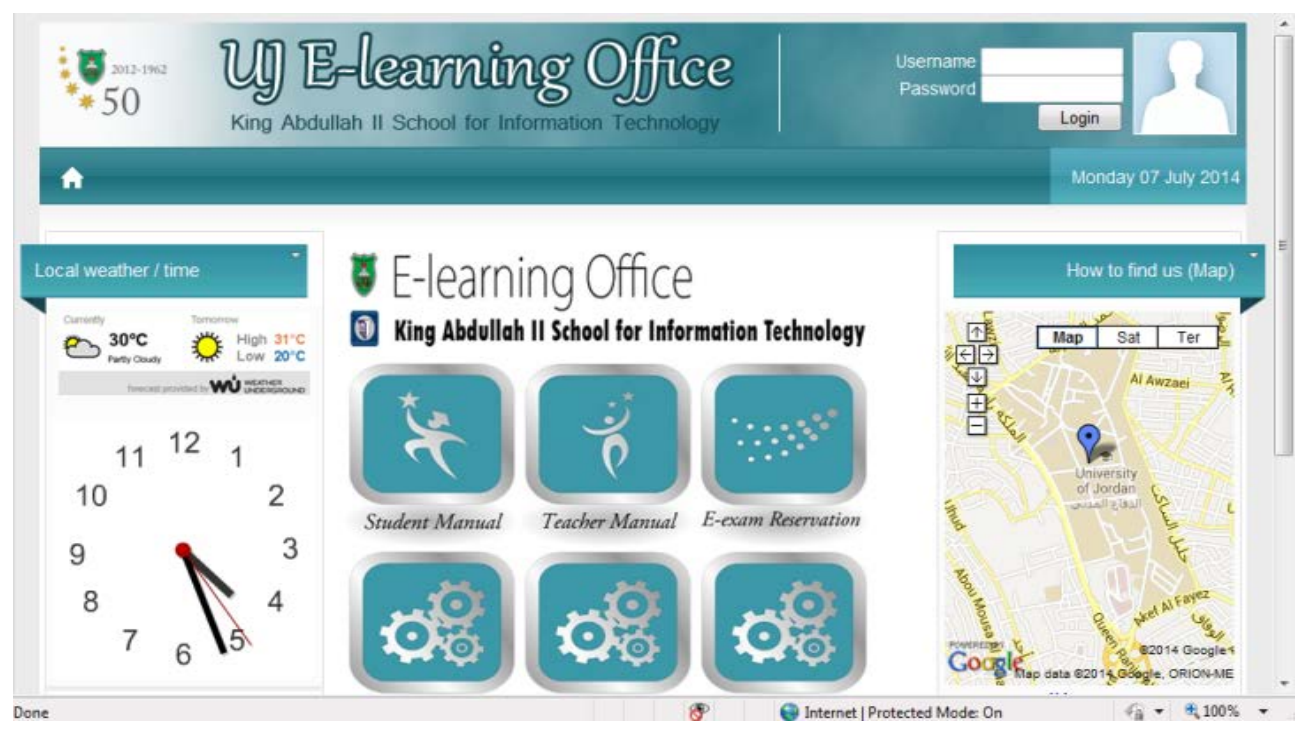

Figure 1. The university of Jordan E-learning platform homepage. 


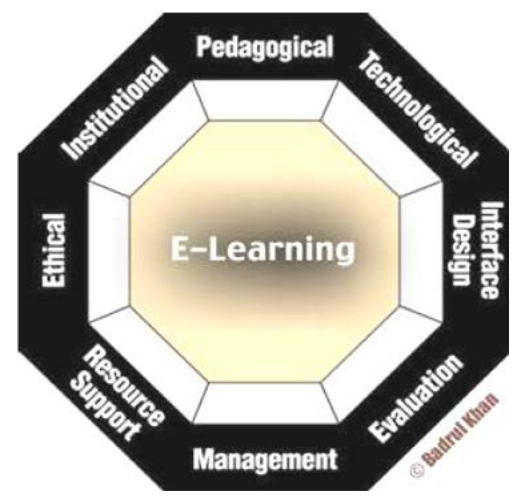

Figure 2. Khan's E-learning framework.

The hexagonal diagram divided into 3 portions. The first portion is related to education, which consists of pedagogical, evaluation and ethical. The second portion is related to technology and interface. The third portion is related to managerial issues, which includes management of resources, institutions and resource support.

Khan's framework is one of the most effective and comprehensive theoretical E-learning model. It can help institutions to evaluate their E-learning readiness or their opportunities for growth.

The dimensions of Khan's framework are:

1) Institutional Dimension: It is concerned with issues of administrative affairs, academic affairs and student services related to E-learning. Three sub dimensions applied at the University of Jordan which as follows:

- Administrative affairs: The University of Jordan has fees related to registration. It provides loans system and has regulations to fund excellent students. It also provides a budget to support scientific research and research projects.

- Academic affairs: Like any other university in Jordan, the University of Jordan follows MoHESR regulations and standards in terms of grading and graduation. For teaching purposes, all class rooms and computer labs are equipped with data shows and most of the teachers have laptops.

- Student services: The students can check their courses' materials, news, download assignments and upload them again. Do on-line quizzes and obtain their grades.

2) Management Dimension: This dimension refers to the maintenance of learning environment and distribution of information. The University of Jordan is considering LMS platform, modifying and updating it by applying text, video lectures, presentations, etc.

3) Technological Dimension: This dimension examines issues of technology infrastructure in E-learning environment, including infrastructure planning, hardware and software. The infrastructure of LMS in the University of Jordan consists of authoring tool which allow for authorized users to add text or any content management. In each course there is messaging system between the teacher and the student, and discussing forums noting that these systems are available but not activated for all courses.

4) Pedagogical Dimension: It refers to teaching and learning. This dimension addresses issues concerning content analysis, audience analysis, goal analysis, medium analysis, design approach, organization and learning strategies. The course website is divided into topics according to the course syllabus where under each topic the students can find lecture notes, slides, video lectures, or assignments.

5) Ethical Dimension: This dimension relates to social and political influence, cultural diversity, bias, geographical diversity, learner diversity, digital divide, etiquette and the legal issues. In the University of Jordan, all the students have equal rights regardless of age, nationality, etc. In case of assignments and exams there are clear rules known by all the students and teachers.

6) Interface Design Dimension: It refers to the overall look and feel of E-learning programs. This dimension encompasses page and site design, content design, navigation, accessibility and usability testing. The LMS course interface is easy to use, attractive, and user friendly. On the homepage of LMS you can find two files for training one for the students and the other for the teachers.

7) Resource Support dimension: It examines the online support and resources required to foster meaningful learning. The University of Jordan has agreements with IEEE and other digital libraries to be accessed from employees and students. 
8) Evaluation Dimension: It includes the assessment of learners and evaluation of the instruction and learning environment. The University of Jordan platform offers an online questionnaire for each course. Based on the results of these evaluations, modifications take place for the teaching process and/or course contents, assessment, etc.

\subsection{Factors Affecting the Students' Acceptance of E-Learning Platform at the University of Jordan}

Usually, new systems fail because the end users do not accept to use these systems. This happens because they do not figure out any benefits from using these systems, or they find these systems too complex which cause a lot of troubles for them. Moodle, as a new LMS at the University of Jordan, can be accepted or rejected by the users i.e. students. Knowing the students' intentions and understanding the factors that influence students' beliefs about E-learning can help academic administrators and decision makers in the universities for creating mechanisms to attract more students to adopt this learning environment [22].

Developing a good LMS is not worthwhile if the acceptance of the technology is still low and the success factors are still unclear. The Technology Acceptance Model (TAM), which is shown in Figure 3, has been applied in various studies for testing user acceptance of information technology in many applications, i.e. Email, voicemail, E-commerce application, word processor, spreadsheet, presentation software, database program, case tools, hospital IS, Decision support system, Expert support system, telemedicine technology, and E-learning systems [23]-[28].

A study at the University of Jordan [29] adopted students from different faculties and different academic years with different Grade Point Averages (GPAs) in 2014 taking into account these three variables as external variables according to the model confirmed that Perceived Ease of Use (PEU) has a significant impact on Perceived Usefulness (PU), as suggested by Technology Acceptance Model (TAM) Theory. Both PEU and PU also have positive effect on Attitude towards using (ATU). The attitude towards E-learning is important. To achieve the promises of E-learning, users need to embrace it and management needs to provide the necessary support. Essentially, if they feel that E-learning creates more problems than it solves or if they simply do not know how to use it, they will not be comfortable with its use, and will therefore demonstrate signs of resistance, thus rendering the E-learning system valueless [30] [31]. Both Perceived Usefulness (PU) and Attitudes towards using have positive effect on Behavioral Intention to Use (BIU).

The study concluded the following findings:

- The results of the research firmed the original TAM's findings and revealed that GPA and the academic year have no significant influence on perceived ease of use while they have affect on perceived usefulness. The faculty has an influence on perceived ease of use and perceived usefulness, which means the decision makers in the University of Jordan, must give more attention to the students in humanities faculties to increase their skills in using computer and internet in their courses and increase their awareness about the benefits of the Learning Management Systems.

- The students of the University of Jordan are highly qualified to use Moodle as LMS and have sufficient awareness of benefits of this system.

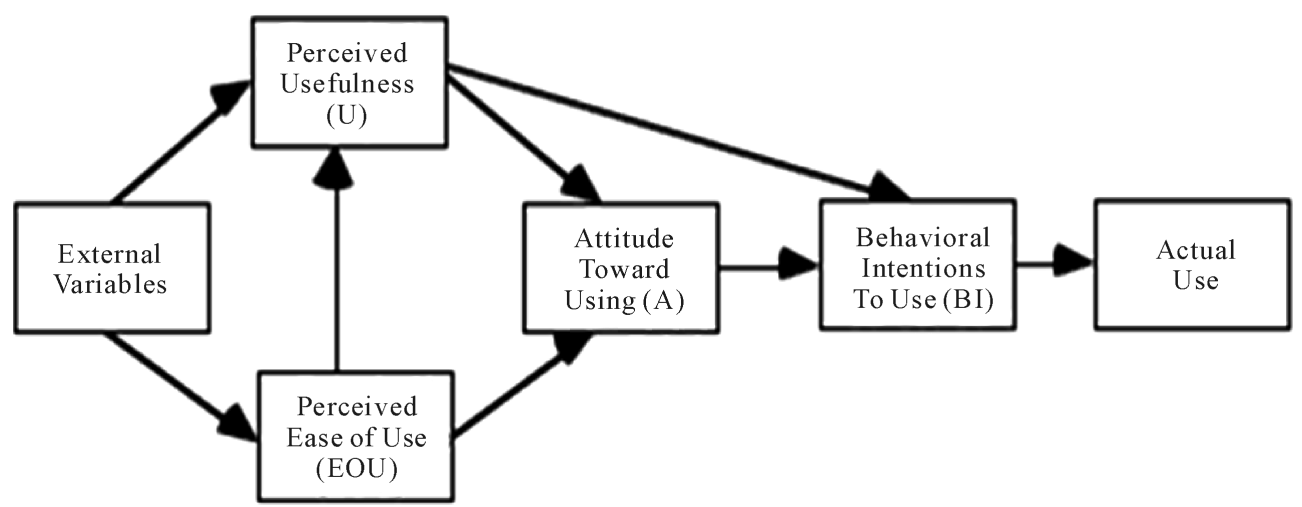

Figure 3. The technology acceptance model. 
- The results showed that the perceived usefulness and perceived ease of use are factors that directly affect students' acceptance toward using Moodle.

- The attitudes of students for using Moodle returned to the perceived ease of use and not for the perceived usefulness which invites the decision makers in the university to increase the awareness of the importance and usefulness of Moodle and other ICT tools.

\subsection{Challenges of E-Learning Platform from Students Perspective}

Researchers believe that one of the goals of introducing E-learning was to revolutionize the learning process, either by facilitating many of the challenges that face instructors and learners daily, or by presenting opportunities that might have not existed before [32].

The experience of [33] shows that implementing E-learning Systems still facing a number of challenges such as cost and IT access especially in developing countries, student's IT skills, performance levels, the benefits, lecturers roles, information ownership, availability of resources, social inequalities of accessing education online.

However, technologies bring challenges as well and merely the presence of a technology does not guarantee successful implementation. E-learning adoption like any other technology adoption is hampered when there is absence of improved technology in any university system. As noted by [34], the successful implementation of E-learning by an educational system should fulfill certain criteria, such as the acquisition of adequate technological infrastructure and adequate educational content of persons with the university skills and a developed culture which encourages learning and sharing of knowledge.

Several studies including [35] have proposed that, distinction had to be made between the various factors that influence adoption and diffusion of information systems including individual [36], environmental [37], organizational factors [38] and technical [39]. Based on a literature review several E-learning challenges have been identified as "Technical Difficulties, access to computers, English competency, need for face to face interaction, level of awareness, computer literacy, resistance to change, student assistance, and privacy and security".

Students undergo a number of problems when taking an E-learning course. Some of these problems were addressed by the University of Jordan's students; such as lacking confidence and experience with the use of computers, lacking skills in commonly used applications, self-motivation and time-management. Some of them are not, i.e. like the language problems, privacy and security, and resistance to change. The researchers developed a small paper based survey and sent to students at The University of Jordan which considered of 240 students from different faculties distributed as shown in Figure 4.

There are many obstacles facing students when using the University of Jordan platform (Moodle) in learning. Some of those obstacles are related to the hardware resources with a mean of 0.7792 followed by defects in the university network (0.5750). Other obstacles related to students facing difficulties in asking for help to work on Moodle or solving technical problems $(0.3292$ and 0.3000$)$. Other obstacles related to students facing difficulties in learning at the computer screen (0.2917). Table 1 shows the means score of students' responses.

\section{Conclusion}

The results of this research provide support evidence to move forward towards E-learning using Moodle as an E-learning platform system at the University of Jordan. There are some obstacles facing students who use Moodle in learning, but these barriers can be overcome if the decision makers at the university give orders to make

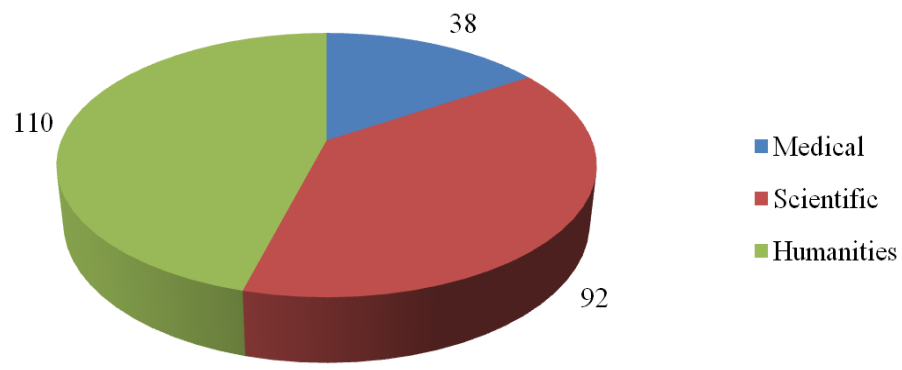

Figure 4. Distribution of the students according to the faculties. 
Table 1. Means and standard deviation of obstacles as perceived by the university of Jordan students.

\begin{tabular}{|c|c|c|c|}
\hline & Question & Mean & Std. Deviation \\
\hline 1 & There are problems in the laboratories (hardware, printers, etc.). & 0.7792 & 0.41568 \\
\hline 2 & $\begin{array}{l}\text { There are problems in the university network affecting negatively on using } \\
\text { Moodle, downloading/uploading assignments and checking the courses news. }\end{array}$ & 0.5750 & 0.49538 \\
\hline 3 & There is no help or guidance from the lab supervisor of how to use Moodle. & 0.3292 & 0.47089 \\
\hline 4 & $\begin{array}{l}\text { There is no help from the lab supervisor in resolving the } \\
\text { technical problems of the devices. }\end{array}$ & 0.3000 & 0.45922 \\
\hline 4 & I find it difficult to read and study from the computer screen. & 0.2917 & 0.45548 \\
\hline 5 & $\begin{array}{l}\text { I do not have sufficient knowledge in using computer, internet, } \\
\text { windows and Moodle. }\end{array}$ & 0.2792 & 0.44953 \\
\hline 6 & $\begin{array}{l}\text { There is no enough time to solve the assignment because the delivery } \\
\text { date is closed to the date of the descent of Duty. }\end{array}$ & 0.2375 & 0.42644 \\
\hline 7 & $\begin{array}{l}\text { I do not have a personal computer or laptop to use it for solving the } \\
\text { assignments and browsing Moodle. }\end{array}$ & 0.2333 & 0.42384 \\
\hline 8 & I don't have skills in computer using. & 0.1708 & 0.37715 \\
\hline 9 & I don't have skills in printing and writing on a keyboard. & 0.1500 & 0.35782 \\
\hline
\end{tabular}

maintenance for computer labs and assign more technical support to these labs which will help the students to overcome the main problems facing them when using this system.

\section{References}

[1] Wang, Y.S., Wang, Y.M., Lin, H.H. and Tang, T.I. (2003) Determinants of User Acceptance of Internet Banking: An Empirical Study. International Journal of Service Industry Management, 14, 501-519. http://dx.doi.org/10.1108/09564230310500192

[2] Tao, Y.H., Yeh, C.R. and Sun, S.I. (2006) Improving Training Needs Assessment Processes via the Internet: System Design and Qualitative Study. Internet Research, 16, 427-449. http://dx.doi.org/10.1108/10662240610690043

[3] Khan, B.H. (1997) Web-Based Instruction: What Is It and Why Is It? In: Khan, B.H., Ed., Web-Based Instruction, Educational Technology Publications, Englewood Cliffs, 5-18.

[4] Koohang, A. and Harman, K. (2005) Open Source: A Metaphor for E-Learning. Informing Science: International Journal of an Emerging Transdiscipline, 8, 75-86.

[5] Hoppe, G. and Breitner, M. (2004) Business Models for E-Learning. Proceedings of the E-Learning: Models, Instruments and Experiences, Essen.

[6] Lee, Y., et al. (2007) Antecedents of Learner Satisfaction toward E-Learning. The Journal of American Academy of Business, 11, 161-168.

[7] Learning Online (2008) An Introduction to E-Learning.

[8] Ismail, J. (2002) The Design of an E-Learning System: Beyond the Hype. The Internet and Higher Education, 4, 329336. http://www.qou.edu/arabic/researchProgram/eLearningResearchs/designElearningSystem.pdf http://dx.doi.org/10.1016/S1096-7516(01)00069-0

[9] Khambari, M.N.Md., Moses, P., Khodaband, R., Ali, W.Z.W., Wong, S.L. and Ayub, A.F.M. (2010) Students' Needs and Concerns: Experiences from a Learning Management System. 2nd International Malaysian Educational Technology Convention, Kuantan, November 2008.

[10] Ozkan, S., Koseler, R. and Baykal, N. (2009) Evaluating Learning Management Systems. Transforming Government: People, Process and Policy, 3, 111-130. http://dx.doi.org/10.1108/17506160910960522

[11] de Porto Alegre Muniz, M., de Moraes, A., Jacobs, K. and Soares, M.M. (2012) Usability Issues in Learning Management Systems (LMS). Work, 41, 832-837.

[12] Alhazmi, A.K. and Rahman, A.A. (2012) Why LMS Failed to Support Student Learning in Higher Education Institu- 
tions. 2012 IEEE Symposium E-Learning, E-Management and E-Services (IS3e), Kuala Lumpur, 21-24 October 2012, 1-5. http://dx.doi.org/10.1109/IS3e.2012.6414943

[13] Ayub, A.F.M., Tarmizi, R.A., Jaafar, W.M.W., Ali, W.Z.W. and Luan, W.S. (2010) Factors Influencing Students' Use a Learning Management System Portal: Perspective from Higher Education Students. International Journal of Education and Information Technologies, 2, 100-108.

[14] Simonson, M. (2007) Course Management Systems. Quarterly Review of Distance Education, 8, 7-9.

[15] Allen, M.W. (2011) Michael Allen's 2012 E-Learning Annual. Pfeiffer, San Francisco.

[16] Roy, A. and Raymond, L. (2005) E-Learning in Support of SMEs: Pipe Dream or Reality. Proceedings of 5th European Conference on E-Learning, Amsterdam, 2005, 383-388.

[17] Peppers and Rodgers Group (2006) The E-Readiness Assessment of the Hashemite Kingdom of Jordan. USAID, Jordan.

[18] Al-Shboul, M., Rababah, O., Al-Sayyed, R., Sweis, G. and Aldreabi, H. (2013) Roadmap to Advance E-Learning Management System at the University of Jordan. Journal of American Science, 9, 531-545.

[19] Al-Shboul, M., Rababah, O., Al-Saideh, M., Betawi, I. and Jabbar, S. (2013) A Vision to Improve E-Learning at the University of Jordan. World Applied Sciences Journal, 21, 902-914.

[20] Almarabeh, T. and Mohammad, H. (2013) E-Learning in the Jordanian Higher Education System: Strengths, Weakness, Opportunities, and Threats. Journal of American Science, 9, 281-287.

[21] Khan, B.H. (2001) A Framework for Web-Based Learning. In: Khan, B.H., Ed., Web-Based Training, Educational Technology Publications, Englewood Cliffs, 75-98.

[22] Grandon, E., Alshare, O. and Kwan, O. (2005) Factors Influencing Student Intention to Adopt Online Classes: A Cross-Cultural Study. Journal of Computing Sciences in Colleges, 20, 46-56.

[23] Sharp, J.H. (2007) Development, Extension, and Application: A Review of the Technology Acceptance Model. Information Systems Education Journal, 5, 1-11.

[24] King, W.R. and He, J. (2006) A Meta-Analysis of the Technology Acceptance Model. Information and Management, 43, 740-755. http://dx.doi.org/10.1016/j.im.2006.05.003

[25] Ma, Q. and Liu, L. (2004) The Technology Acceptance Model: A Meta-Analysis of Empirical Findings. Journal of Organizational and End User Computing, 16, 59-72. http://dx.doi.org/10.4018/joeuc.2004010104

[26] Almarabeh, T. (2014) Students' Perceptions of E-Learning at the University of Jordan. International Journal of Emerging Technologies in Learning (iJet), 9, 31-35.

[27] Yousafzai, S.Y., Foxall, G.R. and Pallister, J.G. (2007) Technology Acceptance: A Meta Analysis of the TAM: Part 1. Journal of Modelling in Management, 2, 251-280. http://dx.doi.org/10.1108/17465660710834453

[28] Lee, Y., Kozar, K.A. and Larsen, K.R.T. (2003) The Technology Acceptance Model: Past, Present, and Future. Communications of the Association for Information Systems, 12, 752-780.

[29] Majadlawi, Y., Almarabeh, T. and Mohammad, H. (2014) Factors Affecting Students' Usage of Learning Management System at the University of Jordan. Life Science Journal, 11, 666-671.

[30] Simmons, D.E. (2002) The Forum Report: E-Learning Adoption Rates and Barriers. In: The ASTD E-Learning Handbook, McGraw Hill, New York, 19-23.

[31] Netteland, G., Wasson, B. and Mørch, A.I. (2007) E-Learning in a Large Organization: A Study of the Critical Role of Information Sharing. Journal of Workplace Learning, 19, 392-411. http://dx.doi.org/10.1108/13665620710777129

[32] Sicilia, M. (2007) Competencies in Organizational E-Learning: Concepts and Tools. Information Science Publishing, Hershey, Pennsylvania.

[33] O’Donoghue, J., Singh, G. and Handy, D. (2003) Higher Education-IT as a Catalyst for Change. On the Horizon, 11, 23-28. http://dx.doi.org/10.1108/10748120310500099

[34] Psycharis, S. (2005) Presumptions and Actions Affecting an E-Learning Adoption by the Educational System Complementation Using Virtual Private Networks.

[35] Macharia, J. and Nyakwende, E. (2009) Factors Affecting the Adoption and Diffusion of Internet in Higher Educational Institutions in Kenya. Journal of Language, Technology \& Entrepreneurship in Africa, 1, 6-23.

[36] Yang, K. and Jolly, L.D. (2008) Age Cohort Analysis in Adoption of Mobile Data Services: Gen Xers versus Baby Boomers. Journal of Consumer Marketing, 25, 272-280. http://dx.doi.org/10.1108/07363760810890507

[37] Gong, W., Li, Z.G. and Stump, R.L. (2007) Global Internet Use and Access: Cultural Considerations. Asia Pacific Journal of Marketing and Logistics, 19, 57-74. http://dx.doi.org/10.1108/13555850710720902 
[38] Seyal, A.H., Rahman, M.N. and Mohammad, A.Y. (2007) A Quantitative Analysis of Factors Contributing Electronic Data Interchange Adoption among Bruneian SMEs: A Pilot Study. Business Process Management Journal, 13, 728746. http://dx.doi.org/10.1108/14637150710823183

[39] Zhang, S., Zhao, J. and Tan, W.W. (2008) Extending TAM for Online Learning Systems: An Intrinsic Motivation Perspective. Tsinghua Science and Technology, 13, 312-317. http://dx.doi.org/10.1016/S1007-0214(08)70050-6 
Scientific Research Publishing (SCIRP) is one of the largest Open Access journal publishers. It is currently publishing more than 200 open access, online, peer-reviewed journals covering a wide range of academic disciplines. SCIRP serves the worldwide academic communities and contributes to the progress and application of science with its publication.

Other selected journals from SCIRP are listed as below. Submit your manuscript to us via either submit@scirp.org or Online Submission Portal.
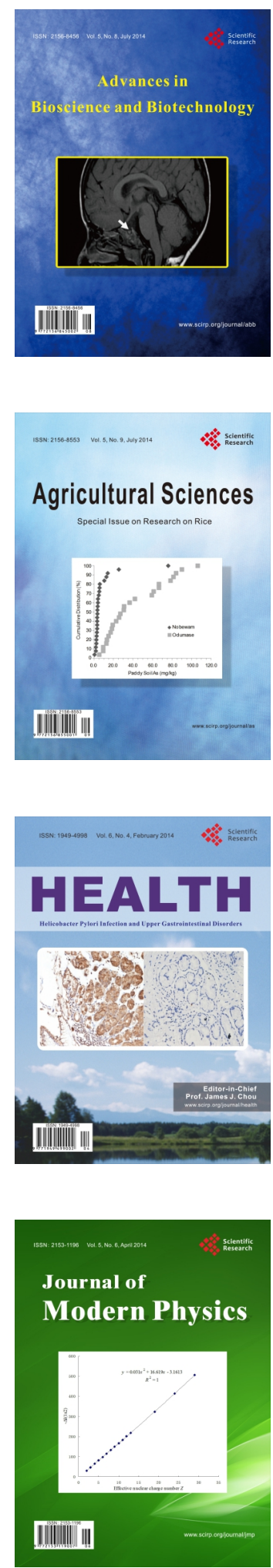
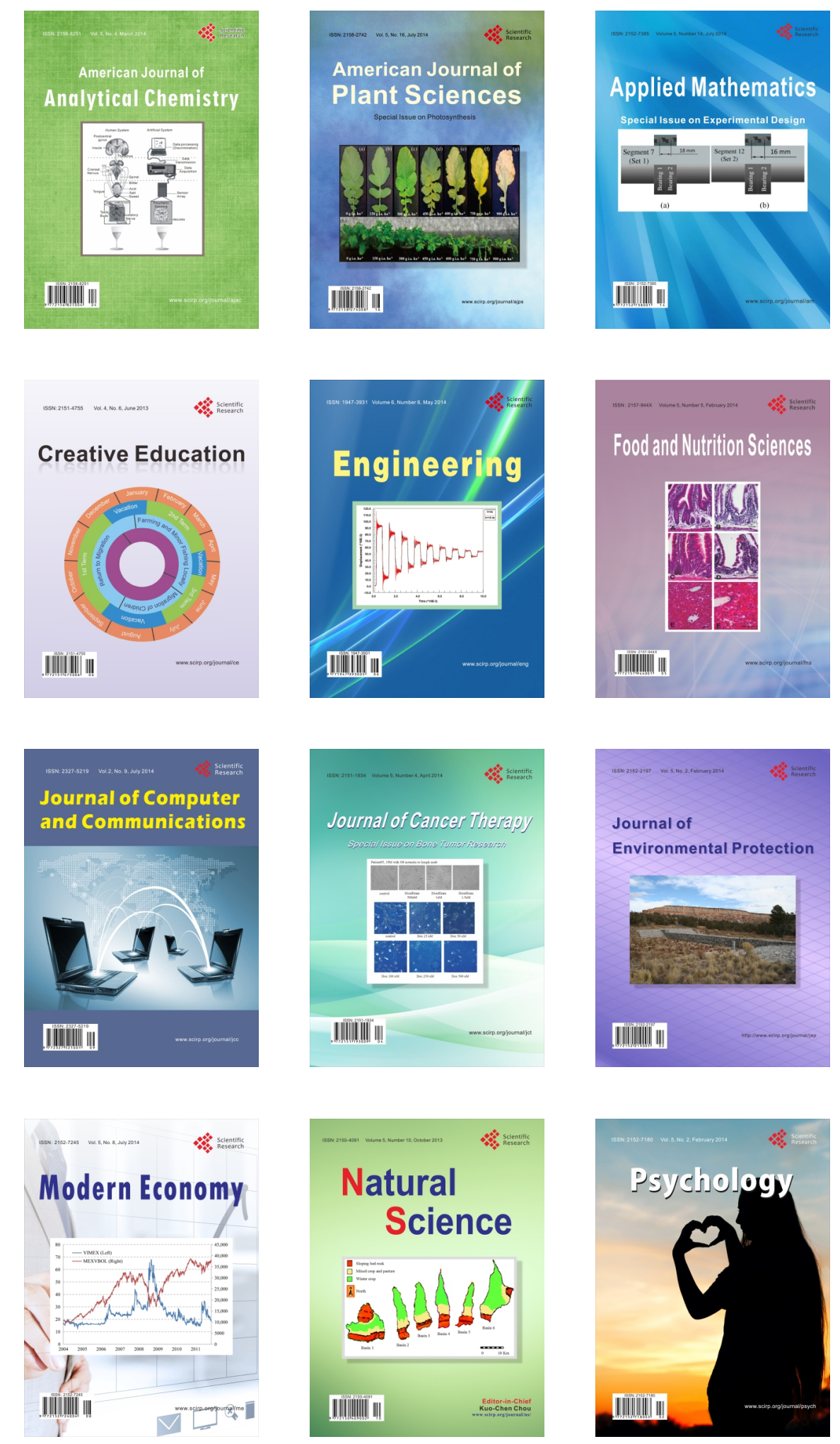